\title{
Corrections and Crime in Spain and Portugal during the Covid-19 Pandemic: Impact, Prevention and Lessons for the Future
}

\author{
Santiago Redondo , Rui Abrunhosa Gonçalves , Javier Nistal , Carlos Soler , \\ José Semedo Moreira, Joana Andrade \& Antonio Andrés-Pueyo
}

To cite this article: Santiago Redondo , Rui Abrunhosa Gonçalves , Javier Nistal , Carlos Soler , José Semedo Moreira , Joana Andrade \& Antonio Andrés-Pueyo (2020): Corrections and Crime in Spain and Portugal during the Covid-19 Pandemic: Impact, Prevention and Lessons for the Future, Victims \& Offenders, DOI: $10.1080 / 15564886.2020 .1827108$

To link to this article: https://doi.org/10.1080/15564886.2020.1827108

\section{曲 Published online: 26 Oct 2020.}

Submit your article to this journal

Q View related articles $\sqsubset$

View Crossmark data $\rtimes$ 


\title{
Corrections and Crime in Spain and Portugal during the Covid- 19 Pandemic: Impact, Prevention and Lessons for the Future
}

\author{
Santiago Redondo a, Rui Abrunhosa Gonçalves ${ }^{b}$, Javier Nistal ${ }^{c}$, Carlos Soler $^{\mathrm{d}}$, \\ José Semedo Moreirae, Joana Andrade ${ }^{b}$, and Antonio Andrés-Pueyo ${ }^{a}$ \\ ${ }^{\text {a }}$ aculty of Psychology, University of Barcelona, Barcelona, Spain; 'bSchool of Psychology, University of Minho, \\ Braga, Portugal; 'General Secretariat of Penitentiary Institutions, Ministry of Interior, Madrid, Spain; ${ }^{\text {dSSecretariat }}$ \\ of Penal Measures, Reintegration and Victim Support, Department of Justice, Barcelona, Spain; ${ }^{\circ}$ General \\ Directorate of Reinsertion and Prison Services, Ministry of Justice and Public Security, Lisbon, Portugal
}

\begin{abstract}
This paper analyzes the impact that the Covid-19 pandemic has had on corrections and crime in the southern region of Europe formed by Spain and Portugal. The main mechanisms of transmission of Covid-19 are the physical proximity between people and the fact of sharing eventually infected targets. In prisons and other correctional contexts people live in close proximity and share the same facilities. As a result, the correctional context has proven to be a critical "hot spot" for the transmission of the Covid-19 pandemic in inmates and correctional staff. First, the magnitude of the infection and their associated health and psychosocial problems (prison incidents, social isolation...) are described. Second, the main sanitary, social, and correctional measures applied to prevent contagion and their related damages are presented (lockdown, use of communication technologies with families, etc.). Third, it is analyzed whether there has been a relationship between the confinement caused by the pandemic and the crime rates observed in Spain and Portugal during this same period. Finally, from the impact in corrections of pandemic and the actions taken to fight it, several important lessons are derived for the future improvement of correctional systems.
\end{abstract}

\section{KEYWORDS}

Prisons; crime; Covid-19; prevention; Europe; Spain; Portugal; Covid-19; Pandemic; Alternatives to incarceration; Early release mechanisms; Prison reform

Wisdom calls to you like someone shouting; understanding raises her voice.

(Proverbs, 8.1)

\section{Introduction}

The year 2020 is likely to go down in history as a dark and fateful year, in which millions of people were infected, and hundreds of thousands became ill and died. There is a terrible historical background to analogous situations (Afonso, 2020; Wade, 2020). In the year 1349, the Black Death killed half of the European population. In 1520 smallpox devastated the American continent and wiped out $60-90 \%$ of the indigenous populations. A century ago, in 1918, the Spanish Flu killed almost 50 million people in the western world. Just over three decades ago, the AIDS pandemic was fatal to thousands of people in all countries and contexts 
(Wade, 2020). Due to its priority transmission by unprotected sex and drug use with contaminated syringes, it had a special incidence in prisons.

This current coronavirus pandemic has been difficult to manage in all countries and contexts. Prisons and other correctional facilities are, by their very nature, places of close physical proximity (the main frequent mechanisms of contagion and transmission ofCOVID-19), particularly sensitive to the impact of this pandemic (Bedford et al., 2020; Hoff et al., 2009; WHO, 2020b).

On March 11, 2020, after 3 months of intense epidemiological monitoring of COVID-19, the WHO officially declared the state of a global pandemic (Contini et al., 2020; WHO, 2020a). It is producing devastating effects around the world in terms of public health, economy, and social relations (Campbell \& Doshi, 2020; Duarte et al., 2020; Ma et al., 2020). Its effects are spreading to all human activities and organizations, including prisons and other correctional systems as well.

The virulent expansion of this pandemic has forced urgent measures to be taken worldwide, sometimes very drastic and comprehensive (WHO, 2020c). They include legal measures of restriction of rights (in general, under the exceptional laws of alarm), confinement of the population in their homes, massive application of health tests, and other mandatory public health regulations (use of face masks, maintenance of social distance, closure of shops and leisure ...).

Analogous measures have also been logically applied in correctional systems, both in prisons and in the community, in order to limit and prevent the expansion and effects of the pandemic on their premises (CPCWG, 2020b; WHO, 2020a). Also, international organizations such as the Council for Penological Cooperation Working Group (CPCWG) of the Council of Europe, the European Organization of Prison and Correctional Services (European Prison Observatory, 2020; EuroPris, 2020a), the Confederation of European Probation (CPCWG, 2020a) or the Association Inter-American Public Defenders of Latin America (IACHR, 2020), have published guidelines and recommendations to adapt the operation of courts, corrections, and juvenile centers for preventing the incidence of COVID-19 on the health of inmates, the prison staff and their respective social environments (family, neighbors, etc.).

This paper primarily analyzes the impact of the COVID-19 pandemic in the correctional systems of Spain and Portugal, in the South of Europe, as well as the prevention measures adopted to prevent its spread. For a better understanding of the significance and consequences of the impact of COVID-19 and the measures applied in corrections, a general sociodemographic, criminal, and penitentiary view of these two countries is presented. Secondarily, although this was not the initial objective of the article, relevant information is also provided here on the evolution of crime in Spain and Portugal during the pandemic and the subsequent lockdown of citizens.

Before offering a current "still photo" (September 2020) of the situation of the pandemic issue in Spain and Portugal, a caveat must be made. Most of the sociodemographic, criminal, and prison data summarized here are quite accurate and valid. However, not all of them equally fulfill these properties for two reasons: firstly, due to the constant change of the COVID-19 epidemiological data; secondly, the absence of information on the medium and long-term consequences (in domains such as health, social, and economic) of this pandemic.

Being aware of these limitations, the sociodemographic data of the countries analyzed in this work, their epidemiological data from COVID-19, as well as their respective crime and 
prison rates, will be presented below. Lastly, the measures adopted in both Portuguese and Spanish penitentiary systems to confront this pandemic will be more precisely contextualized. Given that in Spain the region of Catalonia has a differentiated prison administration, some of the data presented below will also refer specifically to that Spanish region.

\section{Sociodemographic factors and COVID-19 pandemic}

Apart from their different sizes, Spain and Portugal are very similar countries in terms of their sociodemographic characteristics (https://datosmacro.expansion.com/paises/portugal; https://datosmacro.expansion.com/paises/espa\%C3\%B1a). In 2020, Spain had a population of 47,329,981 people with an average age of 43.4 years (19.49\%, over 65) and a female rate of $50.98 \%$. (Within this, the Spanish region of Catalonia has a population of 7,727,029 people, with an average age of 44.02 years $-18.9 \%$ over 65 years- and a female population rate of $50.91 \%)$. Portugal has a population of 10,341,330 inhabitants, with an average age of 44.8 years $(20.7 \%$ over 65$)$ and a female population rate of $52.6 \%$.

The first serious effects of COVID-19 on the Spanish population raised the government alarm in the first week of March 2020 (Millan, 2020). On March 13, the general confinement of the population in their homes and multiple mobility prohibitions were decreed (after approval of the state of alarm provided for in the Spanish Constitution): closure of schools and playgrounds, universities, almost absolute cessation of industrial and commercial activity (except essential services: health, police, and security, food supplies), closure of sports and leisure facilities, hotels, bars, and any public activity in closed and open places. This situation lasted 14 weeks, until June 21, 2020.

Portugal had the first confirmed case of COVID-19 on March 2. Since then, a set of measures were adopted to prepare both community and entities for the outbreak (European Union Agency for Fundamental Rights, 2020). The strict lockdown measures began on March 12 (Portuguese Council of Ministers of March 12, 2020; Sappal, 2020) and ended in early May. Despite the suspicions that, in Portugal, the number of reported cases would be probably underestimated (Duarte et al., 2020; Sánchez, 2020), according to the official data, unlike in Spain, the preventive effect of such measures seemed to be effective, producing a low rate of infections and deaths. During the pandemic, people have been mobilizing themselves to the social distance to prevent virus expansion. However, this protection may be difficult to be ensured for the incarcerated population. Typically, prisons are overcrowded (Aebi et al., 2016; UNODC, 2020) and maintaining the isolation of inmates seems not to be feasible. Over time, because of the massive use of imprisonment not only for violent and dangerous offenders but also for misdemeanors, a growth of the prison population started to be noticed (Coyle et al., 2016). For example, J. M. Byrne et al. (2015) carried out a macroanalysis of incarceration in different regions of the world, highlighting that the global number and incarceration/population rates continued to increase in most countries, despite the fact that in many crime decreased. Indeed, despite the expansion of alternative sanctions in the community, prisons' overcrowding remained a challenge with a significant impact on the conditions provided to the inmates.

To face the spread of the infection and its consequences for the population, both Spain and Portugal have followed the social and health guidelines recommended by the WHO and the health experts of each country (WHO Director-General's Special Envoys on COVID-19 Preparedness and Response, 2020). In both countries, different outbreaks of 
COVID-19 have occurred since the end of the confinement. However, in neither of the two countries the epidemic alarm situations and the severity of the disease are up to now as severe as in the first wave of the pandemic. In Spain, until September2020, the cases of contagion were more of 677,000 confirmed by PCR analysis, with a population rate of detected infection of about $1.42 \%$, and more than 30,663 deaths (a rate of $0.06 \%$ of the general population) (Zafra et al., 2020). In the Catalonia region, which represents the $16.41 \%$ of the Spanish population, more than 102,000 people were infected (a population rate of about $1.32 \%$ ) and more than 5,725 died (a rate of $0.07 \%$ ). In the case of Portugal, data from 28th July indicated that the number of those infected was 69,663 and of deaths 1,925 , representing a population rate of $0.67 \%$ and $0.02 \%$, respectively (DirectorateGeneral of Health, 2020).

\section{Prison population in Spain and Portugal}

Essential information, to contextualize the preventive measures about COVID-19 adopted in the prison systems of Spain and Portugal, concerns the incarceration rates of these countries. Unlike what happened 5 years ago, both prison systems have experienced during the last years, a gradual decrease in the number of prisoners (Aebi et al., 2019; Cid, 2020). Accordingly, the analysis carried out here on the prison impact of the COVID-19 pandemic must be framed in a context of structural decline in prison figures.

In the European countries, in 2018, the average incarceration rate was 112.5 prisoners per 100,000 inhabitants, ranging from 51 prisoners in Finland to 235 in Lithuania (Aebi \& Tiago, 2018). At the beginning of 2020, Spain had a total number of 58,374 prisoners, which implies a prison rate of 123 prisoners per hundred thousand inhabitants (Catalonia has a rate of 110 prisoners), while Portugal has a prison population of 11,053 inmates, corresponding to a rate of 102 (World Prison Brief, 2020).

Globally, Spain, with a rate of 45.6 crimes per 1000 inhabitants, and Portugal, with a rate of 38.2 crimes per 1000 inhabitants, have low crime rates (MI, 2020a; Redondo \& Frerich, 2014; Redondo \& Garrido, 2013). Despite this, their prison sentences tend to be longer than those established in most European countries (Cid, 2008, 2020). This tendency could explain why Spain and Portugal have, despite their low criminal rates, incarceration figures above the European average.

Epidemiological and public health studies (Bedford et al., 2020; Di Lorenzo \& Di Trolio, 2020; $\mathrm{Hu}$ et al., 2020) indicate that the prominent risk factors for increased virulence of COVID-19 infection are being elderly, being male, smoking, suffering from asthma, obesity, diabetes, chronic hypertension, obstructive pulmonary disease, immunosuppression, chronic kidney disorders and having a low level of social development. This last risk factor is a global measure of social disadvantage and structural inequality. It includes poor housing conditions, insufficient hygiene, poor nutrition, drug addiction, smoking problems, and difficulties in accessing health, education, and other personal resources (Hoff et al., 2009; WHO, 2020b).

The prison population is composed mainly of men, from disadvantaged social groups, lower cultural and educational levels (Moreira \& Martins, 2019), and, in many cases, from ethnic, religious, or political minorities. Their health is generally weaker than that of their reference population (Penal Reform International, 2020; UNODC, 2020), with a higher risk of getting infections and developing serious illnesses such as tuberculosis, AIDS, hepatitis, 
or mental disorders (Fazel \& Baillargeon, 2011; Flanigan et al., 2009; Liebrenz et al., 2020; Stoliker \& Galli, 2019). Hence, a simple glance at the aforementioned risk factors and, in parallel, the characteristics of many incarcerated people, allows to easily verify that the prison population may be especially vulnerable to the impact of COVID-19, and particularly to the effects of the type 2 coronavirus causing severe acute respiratory syndrome (SARS-CoV-2) (Bedford et al., 2020; Sanchez et al., 2020). Apart from their special personal vulnerability, prison inmates live in close proximity during their routines, which increases the risk of the coronavirus dissemination (Gonçalves et al., 2019; WHO, 2020b).

Studies focused on other previous pandemics have emphasized the high prevalence of the communicable and infectious disease among correctional populations, particularly prisoners, and the lack of preparedness of correctional services to address this problem and ensure effective care for inmates and other sentenced people (Hoff et al., 2009; Liebrenz et al., 2020). Considering the danger of COVID-19 contagion for those who have a higher risk of illness, protecting the health and wellbeing of the correctional population seems to be a priority to prevent a serious outbreak in both sentenced subjects and prison staff. As noted by Duarte et al. (2020), it is important to make efforts to fight the virus' dissemination based on the lessons learned by other emergencies, such as H5N1 avian influenza, SARS, H1N1 Pandemic and MERS-CoV. Moreover, experiences and lessons from earlier pandemics should be considered not only to enhance the responses to address the risks for physical but also for mental health (Afonso, 2020).

\section{Method}

To collect information for this study, a series of questions were asked to experts and managers of the prison systems of Spain (including the national and the Catalan prison administration) and Portugal. These questions were developed around five main axes: 1) main sociodemographic and correctional characteristics; 2) health impact of the COVID-19 pandemic in the society and in corrections (infections, sick, deceased); 3) measures of lockdown and others within prisons and community corrections (interrupted activities: visits, education, work, treatment...); 4) sanitary (protection, hygiene...) and preventive measures adopted (such as the possible release of prisoners and the use of community measures); 5) lessons that can be derived from this experience for the prison system and future prospects.

The questions raised for the purpose of this work were answered both by sending written reports and verbally. The authors of this work (academic and professional experts in corrections) reviewed, summarized, and consensually ordered the data and information presented here.

\section{Results}

\section{Correctional measures against COVID-19}

Studies developed in the context of pandemic influenza have already underlined the need to develop infection control plans that address the reallocation of the space and regrouping of prisoners (Maruschak et al., 2009). However, other measures should be pondered, particularly to solve the problem of prison overcrowding (UNODC, 2020). Indeed, overpopulation results in a higher risk for any situation of transmittable diseases (Penal Reform International, 2020). It might be recommendable to release those who do not represent a real danger for the society, and who do not have committed violent or sexual crimes 
(UNODC, 2020). In addition, alternatives such as community orders could be a priority, especially for those who are at high-risk risk (such as elderly, prisoners with chronic diseases, and pregnant women) (Penal Reform International, 2020; UNODC, 2020).

Consistent with these and other similar considerations, various measures have been taken to combat the COVID-19 pandemic, both in the countries analyzed here (Spain and Portugal) and in the European countries as a whole. We will begin by describing briefly the European panorama and later, more extensively, what happened in Spain and Portugal.

\section{Europe}

When they became aware of the spread of the COVID-19 pandemic in Europe, the European correctional systems established various measures of confinement (consistent with those adopted by the general health institutions). EuroPris has so far published on its website three reports on the situation of the COVID-19 pandemic and the measures adopted in the prisons of the EU countries. The second report corresponds to April 22, 2020. It includes the following main information (European Prison Observatory, 2020; EuroPris, 2020a; https://www.europis.org/covid-19-prevention-measures-in-europeanprisons/):

- Of the 27 member states of the EU, 21 documented by April cases of infections and quarantines among inmates and staff, while 6 countries had not detected infections. In line with the greater impact of the pandemic in their respective societies, the countries with the highest prevalence of infections were Spain (with 46 prisoners and 238 staff infected) and Italy (with 37 infected prisoners and 163 staff members).

- In all countries, all physical visits related to probation, mediation, and religious services were interrupted (except the interviews, with the necessary sanitary control, with the legal counsel services, the consular officers, and the religious counselors).

- A particularly negative impact of this situation has derived, from the suspension of family visits, for the children of the inmates (women and men). To alleviate these harmful effects, various countries have created support groups for children and packs that imprisoned mothers could send to their children and Family Video Visits.

- Most states interrupted the educational, sports, group, and professional training activities usually carried out in prisons. Although some, if they had the possibility of specialized staff and space, held one-on-one activities, distance learning, or certain workshops. Some workshops have been aimed for the production of protective clothing and masks for health services.

- Generally, the correctional facilities allowed inmates to shower daily and laundry services have remained active.

- Kitchen services have been kept running during de pandemic, but meals were usually held in the cells.

- Providing prisoners with comprehensive and clear information has been critical to an adequate understanding and acceptance of the restrictive and lockdown measures applied. In some cases, telephone information lines were activated for prisoners and their families.

- Different compensatory measures have been used for the negative effects of the situation: more time for phone calls (including defraying the cost of the calls in some cases), 
videoconferences, free television, extra food, and financial compensation (to counteract the suspension of paid workshops).

- Most countries have maintained the use of shared cells (except for infected prisoners).

- Most facilities have medicalized quarantine units to serve those incarcerated with symptoms of infection. In general, medical personnel and access to ambulances and hospitals have been considered sufficient. Infection tests are usually carried out by prison health services or the general health system on prisoners or prison staff who have symptoms of infection.

- Regarding personal protection materials, most countries prescribe the use of masks only for inmates who are infected or at higher risk of infection (when transferred, those who carry out tasks of greater contact with others). However, it is generally expected that the prison staff in direct contact with the inmates will wear protective clothing and mask.

- In coordination with the police and the prosecution office, efforts have been made to avoid new prison incomes (e.g., those sentenced to short sentences or pre-trial prisoners) except for violent crimes. Alternatively, house arrest, electronic monitoring, and fines have been used. Potential new admissions have been medically monitored and quarantined. In some cases, as a result of these measures, a significant reduction in the prison population has been observed.

- Different countries have released in advance prisoners who have been sentenced to short sentences or had certain nonviolent crimes. Aebi and Tiago (2020) have analyzed in the European countries their respective percentages of reduction of the prison population (as of April 15, 2020, during COVID-19' confinement) in relation to the previously existing population as of January 12020 . Various European countries have experienced significant reductions in their respective prison populations: Spain (7.7\%-4,505 prisoners less; according our data), Italy (9.4\%), Ireland (12.1\%), Norway (13.3\%), France (14.4\%), Portugal (11.7\%-1,289 prisoners less; according to our own data), and the Spanish region of Catalonia (17\%).

- With regard to prison staff, in many countries, general preventive measures have been initially adopted: staying at home for staff members with COVID symptoms, chronic diseases, people over 60 and pregnant women. Secondly, a series of specific measures for work in prisons have been applied: creation of small stable work groups, to always work together; spacing between guards; suspension of training courses; temporary suspension of work permits; psychological help.

- Following the same report, most countries were focused by April on the day-to-day life of the pandemic and its prevention; they had not yet begun to make forecasts for possible outbreaks of the infection. Some countries had already started to prepare for the "after lockdown" and a gradual restoration of prison activities and family visits. It was considered that, as a general principle, all these actions should be closely linked to the measures adopted for citizens in the outside.

\section{Spain}

For the management of the health crisis situation caused by COVID-19 in Spanish prisons, the following main measures and restrictions were established (DGEPRS, 2020a, 2020b): 
(1) The suspension of all external communications and of all leave exits, except for reasons of force or extreme necessity. Inmates classified in the third degree (open regime) or in a flexible regime could only leave in the case of having to carry out essential activities such as purchasing food, going to health centers, traveling to workplaces, care of dependent people, etc. (as provided in article 7 of the Decree 463/2020, of March 14, by which the Spanish government declared a state of alarm).

(2) Prohibition of access to prisons of any person (volunteers, collaborating entities, etc.) who are not part of the prison staff, unless their work inside was considered essential.

(3) Suspension of teaching activity and production workshops of external companies.

(4) Suspension of inmates' transfers, except for health of judicial reasons.

(5) Authorization for the inmates to stay voluntarily in their cells.

(6) Establishment of turns in the dining rooms for daily meals, as well as for the inmates' stay in common areas (leisure rooms, playgrounds. ..), in order to promote social distancing.

(7) Carrying out informative talks to the inmates about the current health crisis and the measures adopted for its prevention in the prison facilities.

(8) Free telephone calls for those inmates without resources and installation of free software for videoconferences. For this, more than 200 mobile phones were sent to the prisons to facilitate inmates to make phone and video calls with their families.

(9) Manufacture of masks in the workshops of some prisons.

(10) Permanent distribution of sanitary material supplied by the Spanish Ministry of Health.

(11) Use of military doctors in correctional facilities where necessary. Disinfection of prison facilities by the Spanish Army's Military Emergency Unit.

(12) Suspension of the possibility of voluntary presentation in prisons from freedom, to serve a sentence, except in justified exceptional circumstances.

(13) Possibility of applying random telephone controls (while a telematic control device is installed) to individuals in an open or flexible regime authorized to remain at home.

Various specific measures were also adopted for the management of alternative measures as community service and treatment programs (Fiscal de Sala Delegado de Vigilancia Penitenciaria, 2020). In total, 2,273 educational workshops and 8,884 face-to-face treatment programs were halted with the proper judicial authorization. These programs have been developed as far as possible through telephone or telematic follow-up of the prison staff or of the expert in charge of each activity.

Information campaigns have been carried out with imprisoned subjects about the health crisis unleashed by COVID-19 and about the necessary measures for its prevention. These information campaigns about the pandemic have been especially intense with certain vulnerable groups, such as prisoners with intellectual or developmental disabilities, who have been provided with a document in the form of "Easy Reading." Also, foreign inmates have been provided with information in their own language.

Regarding prison staff, since the beginning of the pandemic, indications, and criteria were established regarding working hours, flexible hours, teleworking, special work shifts for management teams, and videoconference meetings. These measures have reduced the physical presence in prisons of prison staff to the minimum number 
essential in each functional area: offices, interior of the centers, treatment, workshops, training activities, etc.

For the coordination of all these actions, a work team was created, made up of those responsible for all the areas of management and prevention (health, human resources, treatment, security, transfers, material resources, inspection, institutional relations, prison work, and job training). Its actions were managed through telematic communication channels, permanently coordinating with the penitentiary centers.

\section{The Catalan prison administration}

In Catalonia the management of the COVID-19 crisis has gone through three key periods (SMPRAV, 2020b):

(A) Period of confinement (March 13-May 10), when the most intense protection measures were taken in the prison services.

(B) Transition period (May 11-July 19), during which began the recovering of the interrupted prison activities.

(C) Resumption, from July 20, which purpose is recovering the full functioning of the penitentiary system, while maintaining some protection and prevention measures until the pandemic is fully controlled.

Special attention will be paid here to the measures and circumstances of the first period of lockdown (SMPRAV, 2020a), which have been the following:

(1) External barrier measures adopted to prevent the infection from entering prisons:

- Quarantine of 14 days for admissions to prisons.

- Suspension of face-to-face communications between inmates and families.

- Limitation of transfers to cases strictly necessary for security or prison management reasons.

- Suspension of outings and ordinary permits. Extraordinary permits were limited to exceptional cases and with quarantine on return.

- Suspension of the access to the prisons of the collaborating, voluntary and cult entities, except for necessary attention, with the due protection, to the foreign population (cultural mediators), to severe drug addictions cases, or people with intellectual or developmental disabilities.

- Attention by lawyers was channeled through videoconferencing (with the difficulty that bar associations were closed due to community lockdown).

- Avoid contact between inmates of different modules.

- The maximum capacity of group activities was reduced, and protection measures were tightened.

- Prison schools closed at the beginning of the confinement. The contact between the teaching staff and the students (for doing some educational tasks) has been maintained in part through videoconference. The lack of technological and structural means in prisons have not allowed to maintain this activity sufficiently. 
(2) Protection of vulnerable people

At the beginning of the crisis, the health services screened imprisoned people who, due to their age or health vulnerability, had a higher risk if they became infected. From this, 70 inmates were identified, and the following measures were applied depending on their health, social, and legal situation:

(1) Referral to their home (what the law allows in certain cases) or to an external resource where they could be cared for,

(2) Destination to another prison with follow-up by the sanitary services.

(3) Release measures and reduction of the concentration of people in prisons

A relevant initiative in this regard has been to send some subjects, in legal conditions for it, to their own home or to community resources. The two legal figures used for this have been: an increase (from 1.649 cases - 27\% of classified prison population - to 1.916 cases $-30 \%$ of prison population-) of the classifications in the third degree of treatment, or open regime; a substantial increase in the application of community measures (from 302 inmates to 1.694, un increase of $461 \%$ ), which allow subjects to remain in their homes with some controls. This measure has probably had, firstly, a preventive effect of contagion, as there has been a $12 \%$ reduction in the concentration of inmates in ordinary prison units. With this, the region of Catalonia has experienced the largest decrease in the prison population that has occurred in Europe, as previously seen. Furthermore, the extension of the open regime and community measures has not led to an increase in breaches of sentence, but contrary to its decrease (10 breaches of sentence during confinement in front of 18 breaches in the same time interval of 2019). This could indicate that community supervision measures have worked well and that a more open model of prison management is feasible. Although the global increase in social control resulting from the confinement of the population could also have contributed to preventing the breach of sentences.

(5) Maintaining contact with the outside

An increased number of phone and video calls were used in the Catalan prisons in order to maintain the contact of the inmates with their families and other close people. Also, different measures have been taken to keep the prison population and their families informed (by management teams, prison staff, infographics...), both on the individuals' situation and of the measures taken during the lockdown.

(6) Attention to vulnerable subjects

The impact of the health crisis on prisons critically affects inmates with more vulnerability factors, in relation to which the following measures have been taken: a) financial support for inmates without economical resources; b) a plan for action to prevent substance abuse and possible overdoses, including informative actions, awareness sessions with the population at risk, and greater coordination between the different prison teams for the detection and care of cases with a higher risk. Fortunately, the incidence of overdose has not increased during confinement and during the transition compared to 2019. 
(7) Decrease in the prison population

At the same time, during the health crisis, the population of prisons has been reduced, largely as a result of the decline in the activity of the courts and, probably also, by a decrease in the criminal activity during the lockdown. This would have resulted in a 53\% reduction in the number of prison admissions (359 people in the period between March 16 and May 10, 2020; compared to 830 during the same period of 2019).

\section{Portugal}

The Portuguese government, through its Minister of Justice and the General Directorate of Prisons and Social Reinsertion (DGRSP) approved and released the Contingency Plan for COVID-19 as early as February 17 (then referred as containment phase). The structural lines of the Contingency Plan included, in a synoptic way, the following procedures:

(1) Creation of two rearwards infirmaries, one at the Porto Prison and the other at the São João de Deus Prison Hospital in Caxias, for the internment of infected prisoners; and the availability of the security pavilions in two other central prisons. Moreover, eight tents were installed in several other prisons but there was no need to resort to any of these structures.

(2) Since March 9, visits to prisoners were suspended and only resumed, on June 15, in 14 prisons, and on June 24, they already took place in 42 prisons. Visits to the remaining six prisons resumed until the end of June.

(3) Recommendations to prevent the entry of washed clothes or other goods from the outside were also implemented. Since there were security procedures to be followed, a delay between 24 and 72 hours should be considered between its reception and delivery to the inmates.

(4) Facilitating contact with family and friends, allowing for three daily telephone calls lasting 5 min each.

(5) Definition, for each geographical region, of which prison establishments would allow the entrance of new inmates to remain in prophylactic isolation, with due clinical monitoring, for a period of 14 days.

(6) Suspension of transfers of prisoners between facilities, unless security reasons so determine. Work activities with external entities and leisure activities were also suspended. Regarding school classes and professional training, a distance learning procedure was implemented, following the same procedure used in the outside. Moreover, short-term leaves within warden's duties were suspended and there was the possibility of deferring jurisdictional leaves, granted by the Penal Execution Court, over time. Short-term leaves and judicial leaves for prisoners were gradually resumed after the state of emergency was lifted, with returning prisoners following prophylactic isolation and clinical monitoring for a period of 14 days.

(7) Determination for prisons to reassign and to differentiate the schedules of the inmates' daily routines to try to separate, as much as possible, prisoners considered most vulnerable (aged more than 60, with immunosuppression or chronic disease, namely respiratory, hypertension, and diabetes).

(8) Definition of the protocol of procedures to be followed in the case of infection (following the guidelines of public health services). 
(9) Distribution, by all prison clinical services, of a "Protective Kit" for all individuals. Besides, a plan was prepared with the daily needs estimated by each facility, based on the differentiation of each prison. Up till now, a lot of personnel protective equipment have been distributed throughout all the facilities.

(10) A significant part of the civilian workers was put on teleworking and/or in shift work with rotation, following the procedures and recommendations of the public health services, to prevent social and interpersonal contact.

(11) For prison officers, DGRSP declared the Status of Permanent Promptness, in compliance with the declaration of State of Emergency adopted in the country that ceased in accordance with the gradual regularization of activities.

(12) On April 10, Law No. 9/2020 was published stating the "Exceptional regime for easing the execution of sentences and freedom measures in the context of the COVID-19 disease pandemic." This law grants a partial pardon of prison sentences for convicts whose sentences were no longer than 2 years and a pardon for those whose sentences were longer than the aforementioned, if the time remaining time would not exceed 2 years. It was also granted a special regime of pardon for prisoners with 65 years old or more, carrying physical or mental diseases, or with a degree of autonomy incompatible with life in prison in the context of the pandemic. From these two measures were excluded prisoners serving sentences for domestic violence, sexual crimes, or homicides among other violent crimes.

This Law also granted an extraordinary administrative leave for a period of 45 days for prisoners under an open regime who have already successfully enjoyed a judicial leave or to those under common regime who have successfully enjoyed two jurisdictional leaves. Additionally, for those who have successfully handled these leaves, the Court of Execution of Sentences may anticipate the release on parole, for a maximum period of 6 months.

\section{Incidence of the COVID-19 in corrections}

A summary table of the main data on the impact of COVID-19 pandemic in the correctional system of Spain and Portugal is presented in Table 1.

\section{Spain}

In the prison facilities dependent on the central Spanish prison administration, the impact of the COVID-19 pandemic has been much less than that produced in the social community (DGEPRS, 2020d): total infections have been four times less, hospitalizations seven times less, and deaths 10 times less. Specifically, in a population of 49,998 inmates, 3 have died, and in a group of 24,000 prison staff, 5 staff have died. In the context of Catalonia prison administration, 91 inmates had been infected of which, as of July 12, there were 9 active cases. Among the staff, 167 prison staff were infected of which 19 were still active on July 19. During the month of June, the Department of Health of Catalonia carried out a screening through PCR tests on the entire prison population. This screening has resulted in $0.62 \%$ of the ordinary population presenting a positive result in the detection test.

Initially, there was concern about possible violent incidents in prisons, derived from restrictions associated with confinement (this had been the case, for example, in Italy). 


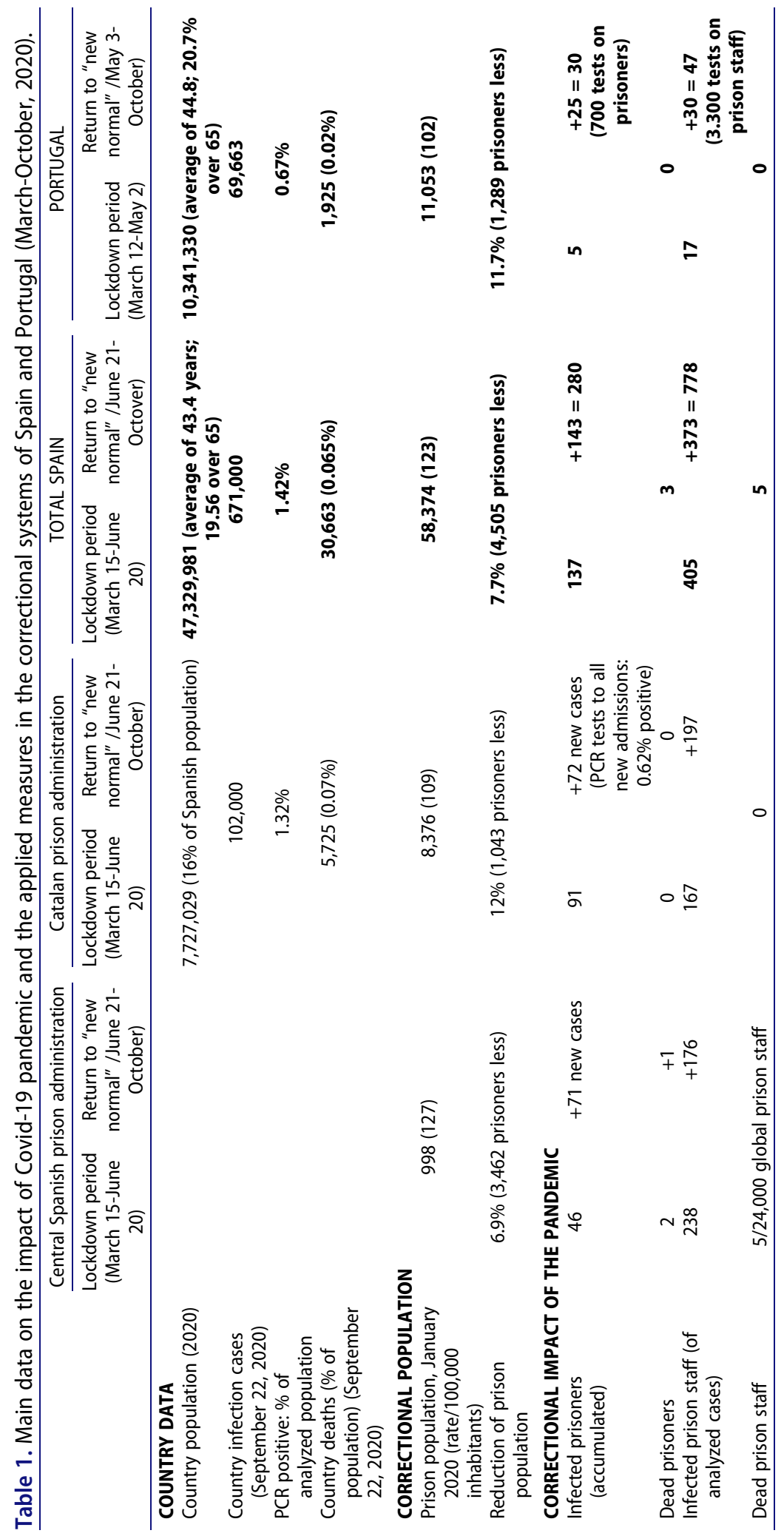


However, fortunately, this concern was soon diluted, as there was a low number of incidents and a low incidence on the safety of the centers.

Connected to this, a relevant effect that must be highlighted is the absence in prisons of deaths from drug overdoses during lockdown (compared to what happened in the same period of 2019, in which six inmates died from overdoses between March 1 and 25 of April). The confinement situation, by causing a forced abstinence from drugs (when its main routes of introduction disappear: visits, convicts who return from a permit...), could in theory have stimulated stress and violence in drug addicts' prisoners. But this has not been the case. Paradoxically, even some drug addicts, forced by the situation to non-consumption, had asked to enter into de-addiction programs through the use of methadone. In Catalonia, despite the stress caused by the health crisis and the measures taken in prisons, the conflicts have not increased significantly. During the confinement period, there was a slightly higher rate of incidents/1,000 inmates (135 compared to a rate of 104 for the same period of 2019). Afterward, the rate has been steadily decreasing: 110 for the transition period and 102 during the "new normal" period (until September 9).

Another striking fact during the pandemic and lockdown is the significant decrease in the prison population $(2020$ c, 2020d, 2020e). In the Spanish prisons administrated by the General Secretariat of Penitentiary Institutions (apart from Catalonia) has been a reduction of 3,462 inmates (between 14 March and June 18). To find a similar reduction in the number of prisoners we must refer to a date as far away as 2002. This net reduction in the prison population results from the difference experienced in this period between the number of prisons admissions (which was 3,847) and the number of discharges $(7,273)$. The lower number of prison admissions was probably related to two connected phenomena during the pandemic: a significant reduction in crime, as will be detailed later; less activity of the courts of justice, as a consequence of confinement.

However, this decrease of prison population cannot be attributed to a significant number of measures of release due to the pandemic. The release measures adopted (community programs, electronic monitoring. . .) have not formally decreased the quantum of the prison population. These measures made it possible for some inmates to serve the final periods of his sentence in more flexible life regimes, out of prison. Specifically, while as of March 13 there were 2,684 convicts serving sentences in an extra-prison regime (telematic means, faceto-face controls, extra-prison monitoring. . .) as of June 18, that figure was 5,670 (an increase greater than $200 \%$ ).

Finally, the irruption of the disease COVID-19 and the measures adopted for its prevention have had a very negative impact, in all countries, on multiple rights and freedoms of citizens (European Union Agency for Fundamental Rights, 2020). These negative effects have probably been worse in prisons, due to their already restrictive nature of rights. These restrictions have drastically limited some of the legitimate rights and interests of those incarcerated (European Prison Observatory, 2020; EuroPris, 2020a; Solar \& Lacal, 2020): cancellation of exit permits, communications and visits, education and training, labor, therapeutic, sports, cultural, religious activities, etc.

To avoid that these limitations of rights (as a result of the pandemic) could become de facto a suspension of such rights, at the Spanish prisons a series of alternatives have been adopted (DGEPRS, 2020a, 2020b):

-Concerning the inmates' right to communications, as mentioned, telephone calls have been maintained with family and friends, increasing their frequency, and adding the possibility of making video calls. Videoconferencing technology has also been promoted 
between prisons and in relation to judicial authorities, the prosecutor's office, lawyers, the ombudsman, consulates, and embassies.

-Regarding the right to exit permits, extraordinary permits have been maintained (for serious reasons) with health prevention measures. Ordinary permit applications have continued to be studied and authorized by the Treatment Boards of the Penitentiary Centers, for their eventual enjoyment after lockdown.

-Regarding the right to prison treatment, face-to-face treatment sessions have continued, with due sanitary measures, by prison technical staff who have continued to carry out their activity in person.

In Catalonia, the pandemic has had a negative impact on the jobs of inmates in the productive workshops developed in prisons (Centre d'Iniciatives per la Reinserció, 2020): $47 \%$ of the collaborating companies have ceased their activity in prisons definitively or temporarily (as of 31 May); part of the employment activity contracted with the public sector has also been affected, except for the production carried out by the healthcare system; as a result, there has been a $35 \%$ reduction in jobs in industrial workshops; the employment of interns has also been reduced as a result of the health and social crisis.

\section{Portugal}

According to the Portuguese Code of Enforcement of Prison Sentences, imprisonment should be applied to protect the society and to enhance the reintegration of inmates by preparing them for the return to the community (Gonçalves et al., 2019). Indeed, the intent to punish criminals should not imply their loss of the right to health care (Hoff et al., 2009; Liebrenz et al., 2020). The sanctions foresee not only offenders' punishment but also their treatment and control (Gonçalves, 2007). Despite this, often, the lack of conditions during the sentences - which is also a result of the prisons' overcrowding - makes difficult the achievement of such purposes.

By June 24, there were three positive asymptomatic cases (enterprise employees providing Services to DGRSP) for COVID-19, contaminated in society. In addition to these three active cases, from the beginning of the pandemic until June 24, were detected another 17 cases that were all recovered. Of these, seven were prison officers, one a medical doctor, two nurses, one a health assistant, and another an administrative assistant. Among detainees, five prisoners tested positive, all coming from community, except one who caught the disease in a unit hospital that had a COVID-19 focus at the time where he had a consultation there.

Since the first positive cases in the DGRSP, reported by the end of March, 700 tests had been carried out by July on prisoners, for screening suspects and contacts of suspects. Starting on May 4, and following a protocol signed between DGRSP and health services, screening tests for prison workers were made available, having already carried out about 3,300 tests on workers and employees assigned to all 49 Portuguese prisons. Until July, there were only four positive cases to COVID-19 (one remained asymptomatic and already recovered while the other three, equally asymptomatic, remain active). This systematic screening currently proceeds in all Portuguese prisons.

Concerning the preventive measures to avoid contagion in prisons, 1,289 prisoners were released under the pardon (article 2 of Law 9/2020), and 701 orders for authorization of Extraordinary Administrative Leave (article 4 of Law 9/2020) were sent to prisons. Besides, 14 acts of grace were conceded. All these release measures provided the creation of 
separated spaces in prisons, allowing for greater social distance both in canteens and in the playgrounds.

A great part of the 45 days leaves have already ended. The guidelines are the renewal of the license, in accordance with the provisions of the law, meaning that successful leaves might imply further authorizations. So far, 10 prisoners have not requested the renewal of these leaves while 12 others did not get the renewal due to unfavorable reports provided by monitoring staff. Additionally, there were 44 revocations for noncompliance with the defined containment rules and three voluntary returns to prison. In this universe of 701 licenses, 84 individuals reach the mid-term of their sentences in the meanwhile and were granted parole, as 12 others who benefit from the pardon. Finally, and until the time of writing this text, among the 1289 released under Pardon, there were 10 returns to prison following the commission of new crimes.

\section{Lockdown and crime}

The analysis of criminality was not the primary objective of this work. However, as the authors delved into the preparation of this paper, a significant relationship was detected between population confinement and crime. Hence, given the relevance of this phenomenon, it has been decided to incorporate this analysis here mainly for the case of Spain. The analyzed data come from official sources (police and judicial) and correspond to the period 2017-2020 (See Table 2).

The first observation that must be made is that Spain and Portugal generally have a low crime rate within the framework of European countries (Aebi \& Tiago, 2020; Cid, 2020; EuroPris, 2020a; Redondo \& Garrido, 2013). These low rates of crime are exemplified below from three types of offenses (corresponding to 2017): crimes against property, homicide, and cars' theft. The comparison unit will be the arrests per 100,000 inhabitants. The crime rates against property in Spain and Portugal were, respectively, 144 and 115 (the European country with the highest rate was Belgium with 167). As for homicide, the highest rate in Europe was that of Latvia, with a value of 5.6 homicides per year for every 100,000 inhabitants. In contrast, Spain and Portugal present identical rates of 0.7 homicides per year per 100,000 inhabitants, which are among the lowest in Europe and in the world. Regarding vehicle theft crimes, the highest rate in the EU was 328 in Luxembourg, contrasting this with that of Spain, which was 69, and that of Portugal, 109.

Given these structural crime figures, what has happened to the crime during these months of lockdown and application of extraordinary measures of control? From the outset, it would be expected that the important changes produced in the social dynamics, regarding the interruption of industrial production, trade, the radical decrease in travel and tourist exchanges, would have produced a global decrease in the rates of criminality (Duwe \& Clark, 2017; Felson, 2006, 2008, 2014; Redondo, 2015; Stickle \& Felson, 2020). The data of the Spanish Police does indeed reflect a generalized narrowing of some crimes during COVID-19 confinement. For example, street crimes have abruptly decreased, up to $80 \%$, including all crimes associated with leisure and tourism activities. This is probably due to the closure of entertainment venues and the almost absolute absence of tourists. Likewise, the dramatic decline in people using public transportation (metro, bus, trains) has also been associated with a significant reduction in crime in these contexts. Offenses related to driving have also deeply diminished during lockdown (up to $80 \%)$, in association with the radical drop in road traffic. 
Table 2. Lockdown and variations in crime in Spain.

\begin{tabular}{|c|c|}
\hline \multicolumn{2}{|c|}{ Crimes that have decreased } \\
\hline Global reported crimes & $\begin{array}{l}\text { 73.8\% (greater reduction in more urban areas: } \\
80.3 \% \text { in Catalonia; } 84.1 \% \text { in Madrid) }\end{array}$ \\
\hline Global reported property crimes & $\begin{array}{l}\text { From } 56,460 \text { (same period of 2019) to } 10,628 \\
\quad \text { (during lockdown) }\end{array}$ \\
\hline Global street crimes & $80 \%$ \\
\hline Thefts & $90.18 \%$ \\
\hline Vehicle theft crimes & $69 \%$ \\
\hline Driving offences & $80 \%$ \\
\hline Frauds and scam crimes & $86.6 \%$ \\
\hline Illegal occupation of buildings & $79.7 \%$ \\
\hline Direct hate crimes & $73.1 \%$ \\
\hline Partner murders & $\begin{array}{l}\text { Reduction from } 4-5 \text { monthly murders to a total of } \\
5 \text { murders over three months }\end{array}$ \\
\hline Juvenile delinquency & $\begin{array}{l}\text { Drastic reduction, according to the Spanish } \\
\text { Juvenile Prosecutor's Office }\end{array}$ \\
\hline Police arrests (two first weeks of lockdown) & 77.94 \\
\hline \multicolumn{2}{|c|}{ Crimes that have not decreased, but rather modified their topography } \\
\hline Drug trafficking & Use of couriers or taxi drivers as drug dealers \\
\hline \multicolumn{2}{|c|}{ Crimes that have increased } \\
\hline Cyber-crimes associated with domestic violence & $\begin{array}{l}\text { Increase in phone calls to police and family } \\
\text { support services }\end{array}$ \\
\hline $\begin{array}{l}\text { Probably frauds by internet, cyber-bulling, grooming sexting, } \\
\text { "malware", hate crimes online, hoaxes and "fake news" }\end{array}$ & Increased "cyber" space \\
\hline $\begin{array}{l}\text { Detainees for resistance and disobedience (generally to police } \\
\text { requirements to comply with sanitary restrictions) }\end{array}$ & $519 \%$ increase \\
\hline
\end{tabular}

In contrast, other crimes have not exactly decreased, but they have varied in topography to adapt to the social circumstances of the pandemic. For example, drug trafficking has taken advantage during the confinement of new distribution mechanisms (couriers, taxi drivers...); thefts have focused on pharmacies and supermarkets (which were open as essential services).

Opposite, the crimes that take place in the "cyber" space have exploded during the lockdown. Cyber-crimes associated with domestic violence have in general increased, if telephone calls to aid services and police interventions in family contexts are taken into account. However, some sexual and gender cyber-crimes have decreased. In particular couple murders in Spain have dropped sharply, from an average of 4-5 monthly murders to a total of five couple murders during the 3 months of confinement. Nevertheless, as for economic and other cyber-crimes, it is early to know the criminogenic effects of the pandemic in family and sex crimes, since many of them can be discovered with significant temporal latency.

Criminal phenomena such as scams or frauds, "pishing," cyber-bullying, grooming, sexting, "malware," hate crimes online, hoaxes, and "fake news" have been triggered for structural reasons. The "cyber" space has become the new reality of the main social exchange: such a high volume of cyber-interactions -even if only for epidemiological reasons- the increase in these crimes is probably been favored (Miró, 2011; Ngo \& Paternoster, 2011; Redondo, 2008, 2015).

The Spanish National Police published on May 1, 2020, a report that compares, firstly, the rates of reported crime between 2019 and 2020, for two defined intervals: from March 1 to 13 and from March 14 to 31 (for 2020, before sanitary confinement and during confinement). Data show an increase in crime in 2020 of $8 \%$ in the first period 
(without confinement) and a decrease of $73.8 \%$ in the second (with confinement), in contrast to the same periods of 2019. The police of Catalonia also informs that during the lockdown the reported rate of crimes decreased by $80.3 \%$ in relation to the same period of 2019. Contrarily, once the confinement ended, a clear increase of crime has been observed, although not up to the same criminal level that existed in 2019, only half of that previous level (Mossos d'Esquadra, 2020).

These data show that in Spain the crime rate has changed in the context of the COVID19 crisis in a very sensitive way (following a dose-effect pattern): where the epidemic has been more serious, the offenses have decreased more. For example, in the region and city of Madrid, where the epidemic has been especially critical, in the first months of confinement crime reached a reduction of $84.1 \%$, significantly greater than the average reduction in Spain of 73.8\% (MI, 2020a, 2020b; Policía Nacional, 2020).

As expected, the largest decreases during lockdown have occurred in property crimes. An analysis of 2 months (March-April 2020) shows that 10,628 property offenses were reported to the police, in front of 56,460 informed in the same period of 2019. Crimes of scam decreased by $86.6 \%$ and those of illegal occupation of buildings by $79.7 \%$. Thefts (which are the most frequent property crime) decreased by $90.2 \%$, from 23,200 known cases in the second half of March 2019 to 2,278 in the same period of 2020. The depletion in other less frequent crimes, such as hate crimes, was $73.1 \%$.

The reduction in the number of reported crimes has also been reflected in a decrease in police arrests: there would have been only 12,047 arrests during the first two weeks of confinement compared to 54,634 during the same period of 2019 (77.9\% less). In contrast, the detainees for resistance and disobedience to authority (generally, disobedience to police requirements to comply with the restrictions derived from the state of alarm) increased during confinement by $519.1 \%$ (reaching 6,700 arrests).

What has happened to juvenile delinquency (vandalism, youth gangs, etc.) during the lockdown resulting from the COVID-19 pandemic? Although there are still no detailed reports in this regard, there are indications that many juvenile offenses have decreased. The prosecutor in charge of the Juvenile Prosecutor's Office in Spain has stated that "since the State of Alarm was declared in Spain due to the coronavirus pandemic, the rate of crimes of minors has decreased dramatically." And similarly to what happened in the adult crime, there was also a "certain rise, during the first fortnight of the confinement, of intra-family violence committed by minors, especially against their brothers or parents"; as well as a decrease in this violence in the first two weeks of lack of confinement (Declarations from the prosecutor to a TV news network, 4/26/2020).

\section{De-escalation planning and resumption of normalcy}

As above-mentioned, many countries are in the de-escalation stages of the previous sanitary confinement, and back to "new normality." However, there is great uncertainty about the future evolution of the pandemic, and about the possible measures that must be adopted, including the possibility of new infections and new lockdowns. Corrections logically do not escape this uncertainty about the future. In both Spanish and Portuguese prisons and community corrections, transition processes toward unconfinement begun with the aim of recovering the main programs and activities related with prisoners' lives (i.e., communications, exit permits, an increase of open regime, return of volunteers, collaborating 
entities, education, treatment programs, face-to-face attention of the social services, visits at home, etc.).

However, this return of correctional institutions to "normality" continues to be subject to various eventualities and shocks, depending on the evolution of the pandemic in each country. So that, let us summarize the evolution of the pandemic in recent months and the measures applied in the correctional systems of Spain and Portugal as well as globally in Europe.

\section{Spain}

As commented, on June 20, the period of "new normality" began in Spain. As of the end of June, all the prison activities that had been suspended during the declaration of the state of alarm were gradually restored (DGEPRS, 2020f, 2020g). As expected, with the restoration of the inmates' contact with the outside world (exit permits, visits. ..) some infections began to appear in various prisons, particularly in the Spanish regions and cities with the highest incidence of outbreaks (including Madrid, the Basque Country, and other). Overall, the accumulated number of infected prisoners since the end of the state of alarm until the beginning of September was 71, out of a prison population of 47,703 inmates (a total of contagious since March to September of 117 prisoners, a figure still four times less than that observed in the general population). As a consequence of these new infections, family and intimate visits were temporarily suspended in the prisons of the risk regions (DGEPRS, 2020h).

Nevertheless, a positive fact in this context is that the Spanish prison authorities have decided to maintain, with the proper prevention measures, the resumption of school activities from the month of September (DGEPRS, 2020i). Contrarily, an especially negative fact is that, since the reestablishment of family visits, there has been a significant increase of deaths in prison due to drug overdoses. This points to the plausible hypothesis that a large part of the drug would enter the prison through these visits.

Regarding the open regime (DGEPRS, 2020j), as of March 13 (before the pandemic), there were 2,684 inmates serving their sentences in an extra-prison life regime (through the use of telematic means, face-to-face controls, monitoring by community institutions, etc.). As of June 18 (at the end of the critical stage of the pandemic) that figure was 5,670 individuals, that is, almost 3,000 more. As of August 5, in the unconfined phase, the number of subjects in the extra-penitentiary regime had decreased to 5,176 .

In Catalonia, between June and July, the routines of contact of the prisoners with the outside, also interrupted during confinement, were progressively recovered. The number of cases of infection remained quite stable in relation to the beginning of the transition phase: on May 10 there were 10 active cases and 61 accumulated in Catalan prisons and on July 20 there were 9 active cases and 102 accumulated. However, in anticipation of the existing risks, it was agreed to once again suspend face-to-face family communications and leaves of those inmates residing in geographic areas with outbreaks of the infection. PCR tests were also carried out on new admissions to prison, with the corresponding period of preventive quarantine until the result of the test was known (SMPRAV, 2020c).

As of September 9, there were 16 active cases in Covid-19 in the prisons of Catalonia and 72 new infected cases. Among the personnel, 24 positive active, and 197 new infected (Internal data of the Department of Justice). Nonetheless, the interrupted activities were 
partially recovered (exit permits; face-to-face visits, with limitations in the number of visitors and the duration: SMPRAV, 2020d).

Since the beginning of the crisis in Catalan prisons, two main actions, as referred, were carried out, aimed at reducing the concentration of inmates in ordinary prison units: 1) increasing the open prison population; 2) refer as many prisoners as possible, with proper controls, to remain in their own homes or inappropriate community resources.

These measures had had a great impact in everyday operation of open prisons. Before confinement, $65 \%$ of the inmates of such open centers (801 people) occupied residential places: they could be away during the day and on weekends (work, family life. ..), but had to return at night. The remaining prisoners in the open regime (35\% of them) were authorized to remain continuously in their homes or in the assigned community resources. However, with the Covid-19 pandemic, the high concentration of people in these open units, but which daily contact the outside world, posed a high risk of infection and spreading the virus among all residents. For this reason, it was established that the majority could remain in their homes, without the obligation to return to the center at night. This drastically reduced the occupation of residential places in open regime, to a minimum of only, as of May 13, of 40 people (3.44\% of the total of the places theoretically available in the open regime). This made it necessary to quickly modify the supervision procedures for these prisoners authorized to reside in the community. Face-to-face contacts and community visits by the staff of open prisons were reduced to a minimum, with supervision carried out through telephone calls, video calls, and geolocation, in addition to the regular use of electronic controls.

However, with the gradual return to the "new normal", a part of the previous residential occupation of the open prisons has been recovered: $22.6 \%$ (232 people) as of July 22 and $29.7 \%$ (312 people) at September 9. Even so, it is considered a priority to maintain a low residential occupancy of the open regime, and to maximize the protection measures against contagion in these facilities.

A final relevant issue here is to what degree the impact of the pandemic in the correctional context has been able to affect the private sector that provides services and technology to the correctional system. There is a growing international trend toward the privatization of the correctional systems, regarding the management of both institutional and community corrections (J. M. Byrne et al., 2019; J. M. Byrne et al., 2015). It is true that in most European countries, including Spain and Portugal, the majority of correctional services are currently developed by the public sector of the government (generally, ministries of Justice, Interior, Health, Education). But so is it, as J. Byrne et al. (2019) have documented, that in various countries, including Spain, some services related to food, health care, maintenance of facilities, rehabilitation, and video surveillance have been privatized. For example, in Catalonia, part of the rehabilitation and reintegration programs (drug addiction, community reintegration, care for the disabled, residential units in the community, etc.) are contracted with private entities (NGOs). During the health crisis and confinement, out of 55 contracts in program developed by external entities (with a budget of five million euros), 5 contracts had to be interrupted. Nevertheless, this has not led to an economic decrease for the providers, but they have been compensated for the time they have not been able to provide their services in prisons. 


\section{Portugal}

From March 1 to September 7, there were 57 cases of Covid-19 in the Portuguese prison system. These 57 cases, mostly asymptomatic, concern 30 workers (15 from Prison Administration staff and 15 from private companies that provide/sell services to DGRSP), 25 prisoners, and 2 juveniles from educational centers. At the present date (September 7 , 2020), there are 12 active cases of Covid-19, all of them related to prisoners previously in freedom. These cases were detected during the quarantine to which are subjected newcomers or furlough prisoners from society. Five cases were persons handed over by police after arrest and court confirmation. The other seven were returning prisoners after benefiting from Extraordinary Exit License (art. 4 of Law 9/2020 of April 10), jurisdictional exit license, and short-term exit license. The remaining 45 cases - 15 of DGRSP workers, 15 of workers from private companies providing services, 13 of prisoners, and 2 juveniles in educational centers refer to people who have already recovered from the illness (available on https://dgrsp.justica.gov.pt/Estatísticas-e-indicadores).

Concerning the adopted measures, between January and August this year, the operative activity of the Portuguese correctional system experienced a sharp drop, except for the penalties and measures inspected by electronic surveillance. This decrease was of $20.33 \%$ failures in technical assistance to judicial decision-making (reports and hearings; Estatística Mensal das Penas e Medidas com Vigilância Eletrónica, August 2020) and 12.49\% in penalties and measures being implemented in the community (Assessoria Técnica à Tomada de Decisão Judicial Execução de Penas e Medidas na Comunidade Áreas Penal e Tutelar Educativa, August 2020). In the opposite sense, only the penalties and measures inspected by electronic surveillance increased by $9.03 \%$. In addition, in the juvenile area, technical assistance for judicial decision-making (reports and hearings; Estatística Mensal Centros Educativos, August 2020) decreased by $23.01 \%$, the measures being implemented in the community fell by $16.89 \%$ and the number of young people confined to juvenile facilities decreased by $18 \%$ (see https://dgrsp.justica.gov.pt/Estatísticas-e-indicadores).

Although is too early to draw definitive conclusions regarding these declines, it is possible that these breaks result from the combination of a decrease in the work of the courts (suspension of hearings and trials) and the confinement rules accorded for people in general. This aspect reduced the exposure of potential victims and therefore affected the rates of low-intensity criminal activity that tends to be the main cause for imprisonment.

The issue related to the impact of Covid-19 pandemic in the private sector providing services to the correctional system does not strictly apply to Portugal, since no private sector supply areas of activity that remain under the jurisdiction of the General Directorate of Reinsertion and Prison Services. Accordingly, electronic surveillance, community measures, and juvenile justice depend entirely on organic units of this General Directorate and are under state responsibility. When it comes to service providers, we refer to providing meals and cleaning central services or security services, in the case of educational centers for juveniles. At a state level, there were no dismissals, maintaining the tenders for hiring new workers that were planned, as it is the case of the tender for the admission of new prison guards. 


\section{Europe}

The most recent report from EuroPris corresponds to July 24, 2020. Its most important insights in relation to the evolution of the pandemic in European correctional systems are the following (EuroPris, 2020b):

-In most countries, the strong restrictions at the start of the pandemic have been relaxed. However, in general, correctional systems continue to experience great pressure to lessen the impact of Covid-19. There is concern that the prolongation of this situation could diminish the motivation of the staff and increase the dissatisfaction of the inmates.

-The most severe impact of the pandemic in prisons is the restriction of family visits (number of visits and visitors, duration of visits...), which largely continues today. A good palliative mechanism has been videoconferences, which have allowed prisoners to have more frequent and extensive contacts with their families; and even the possibility, in some countries, of being able to read bedtime stories to their children. However, it is appreciated that videoconferences should be a complementary instrument, but not a substitute for inperson visits.

-There is great variability between countries on the greater or lesser obligation to use masks within correctional facilities: from the obligation to always use them to their occasional use for certain contacts or activities.

-In many countries, tests are carried out (similar to the community) to those who present symptoms (either prisoners or staff members) and to all those people with whom they have had contact. In some systems, random tests are also performed on the inmates and the prison staff.

-In most countries, medical care for prisoners is face-to-face, although many correctional systems have generated complementary remote health consultation services.

-As a health protection mechanism, many countries try to reduce the prison occupancy rate through measures such as the following: early release, suspension, or postponement of the application of sentences, increased community measures, increased prisons' capacity, or use of single-person cells.

-Among the measures adopted that have shown greater effectiveness in managing the pandemic in prisons are: the combination of restriction of visits, exits from and admissions to prison; the application of compensatory measures with the prisoners (video colling, distant education); clear and continuous communication on the measures adopted and their justification; the provision of sanitary protection equipment to the prison staff and their access to Covid-19 testing.

\section{Discussion}

The global health crisis due to COVID-19 is causing a serious stress in all societies, who have suddenly seen threatened the health of their citizens, their economies and, more globally, their way of life. The impact of this pandemic on the correctional systems has also been acute, including both the inmates (and their families) and the prison staff (Ashby, 2020). To fight this crisis in prisons and other correctional facilities, extraordinary restrictive measures had to be adopted, for preventing the epidemic itself and for minimizing the negative effects of the applied restrictions. The results obtained can probably offer us some important lessons in order to improve and strengthen the prison system when the crisis is over. 
Fortunately, the infections by Covid-19 have been few by now in the prison systems of Spain and Portugal, probably due to the prompt adoption of the diverse preventive measures referred in this paper (lockdown, suspension of visits and exit permits, interruption of education and work programs...); the commendable "professionalism and dedication" of prison staff and managers; the excellent response of the inmates (aware of the seriousness of the situation); the availability of appropriate infrastructures that allowed the inmates to be in acceptable conditions of comfort and well-being.

Among the critical measures adopted has been the almost absolute suspension of the external visits of inmates with their family and friends. Adaptation to life in prison is usually very difficult for inmates, particularly due to the lack of frequent contact with their relatives. For example, a study of Gonçalves and Gonçalves (2012) in Portugal showed that a reduced number of prison visits was associated with a higher level of aggressiveness and a lower level of adaptation to prison live. If the isolation is in principle desirable to protect the virus' dissemination, this deprivation may increment at the same time the prisoners' psychological vulnerability (Afonso, 2020) for experiencing some mental and emotional disorders as higher levels of anxiety and stress (Liebrenz et al., 2020).

To deal with such problems, during the crisis, a relevant strategy has been to maximize the information given to inmates and their families (as well to the prison staff) to involve them in the responsibility of preventing contagion within prisons. As a favorable consequence, their understanding and collaborative responses have contributed to a better management of this critical situation. In particular, the established "family telephone service" with the prisoners' families have proven to be a very successful initiative to improve the quality of the support offered to inmates and their close contexts, to which they will later return. In this framework, actions have also been taken (in collaboration with health services, social organizations, and families) to prevent drug use within prisons and the risk of drug overdose. For those measures, the use of the new devices and advances in communication technology has been greatly accepted for all the users. The lesson learned is that these communication mechanisms, extremely useful for the daily dynamics of prisons, should be consolidated as a stable complementary prison service for prisoners and their families, beyond this crisis.

During the lockdown, something has happened that has profound implications for the prison system, and more broadly, for the entire penal system. Throughout the most severe stage of the pandemic, the prison systems of Spain and Portugal have applied more openended and community-based measures to thousands of prisoners. These measures, which decrease the concentration of inmates in prisons by $9 \%$, probably contributed to the prevention of massive infections within prisons. But, beyond this, these open-ended and community measures could have favored the processes of social reintegration of the released prisoners (without a significant increase in new crimes being observed). From now on it would be necessary to assess precisely to what extent this provisional discharge may have truly favored a greater social adjustment of individuals. If such analysis reveals that discharged offenders were able to start a new non-criminal life, new policies regarding community sentences for other offenders could be considered.

With the return to "normality," although the population in open regime remains in a significantly higher proportion than before, the global rate of inmates residing outside the prison has decreased. Some prosecution and penitentiary surveillance courts are revoking 
part of the previous applications of this measure, understanding that its use was exceptional for the health crisis but not necessary or convenient in a "normal" situation.

The authors of this article want to express their opinion contrary to these restrictive considerations. In the advanced societies of the 21 st century, it is certainly anachronistic to continue to attribute to prison sentences primarily punitive purposes, instead of those of rehabilitation and social reintegration, particularly for nonviolent offenders (Atkin-Plunk, 2020; Moss et al., 2018). For that, the measures of approaching ex-offenders to their family and social context have proven to be a critical factor (Cullen, 2007; Duwe \& Clark, 2017; Martín et al., 2019; Redondo, 2017). Going even further, J. M. Byrne et al. (2015) concluded, based on their international macro-analysis of incarceration, that in order to significantly improve the current negative prison reality (disproportionate rates of prisoners, overcrowding, recidivism...) it would not be enough to improve the quantity and quality of rehabilitation prison programs: "[It] will not fundamentally change the life course of prisoners, resulting in continued high return-to-prison rates for these offenders. (...) For the United States [and this could also apply to most of the countries of the world] ... we will need to rethink our approach to crime and punishment (...) we call for the development of corrections and sentencing policies - and the hiring of corrections personnel - based on the new goal of corrections: individual and community rehabilitation" (p. 421). In other words, in the opinion of these authors, correctional systems are in need of more than just improvement: they need, as they have literally pointed out in the title of their paper, a "Global Rehabilitation Revolution."

Although the analysis of crime was not an initial objective of this work, the authors have considered it important to incorporate it here. In particular, the analysis made of the evolution of crime in Spain has shown a spectacular reduction in crimes during confinement $(73.8 \%)$, in comparison to the same period of 2019 and the periods before and after the confinement. Some criminological theories and multiple empirical studies have endorsed the importance that social exchanges, and the criminal opportunities generated by them, have as precipitators of crime (Felson, 2008; Redondo, 2015; Stickle \& Felson, 2020). Probably, the abrupt reduction in social exchanges (as a result of lockdown) has produced a decrease in the opportunities for "common" crimes on the street; while the return to social and urban relations (at the end of strict lockdown) has been linked to a further increase in street crime (Lum et al., 2020).

Opposite, during lockdown there have been an increase in cybercrimes, which some experts have estimated around 70-80\% (Mossos d'Esquadra, 2020). Just as criminal opportunities for street crime would have diminished, confinement might have favored increased opportunities for certain family crimes and cybercrime (by spending more time at home and making greater use of communication technologies and social networks). Within this framework, there could have been also an increase of certain personal and social criminogenic risk factors, such as the perception of a greater anonymity and impunity, increased economic or emotional needs, or group influence and pressure; and, in parallel, a decrease in some protective factors as social control (physical absence of teachers, more unsupervised leisure time...). This combination of increased risk factors and decreased protective factors could have contributed to the increase, for example, of family offenses and cybercrimes.

As lockdown has been linked to a sharp decline in street crime (up to $70.3 \%$ in the first 15 days of confinement), the return to normality (the so-called "new normality," without strict 
confinement) has been associated - as if it were a "natural experiment" - with an intensive increase in crime, especially street crime, such as theft, robbery, drug trafficking, road crime, etc. Other crimes that have experienced ups and downs, in a reactive manner to confinement/lack of confinement, are cyber-crimes, family violence, crimes at work and the economic context, hate crimes and terrorism.

All these observations clearly endorse the decisive role played by social exchanges, and the opportunities created by them, in the generation of crimes (Stickle \& Felson, 2020). Certainly, not in an absolute and exclusive way, but in conjunction with the risk factors and criminal motivation of the individuals themselves (Bobbio et al., 2018; Farrington et al., 2012; Redondo, 2015; Reyns et al., 2014; Ward \& Fortune, 2016). These results on the impact of this pandemic on crime, which were not initially the object of this analysis, has, however, relevant implications for basic criminological investigation. The time ranges, prevalence, variability, and idiosyncrasy of the evolution of each type of crime should be analyzed with greater precision hereinafter.

In conclusion, the prison systems of Spain and Portugal have quickly put in place multiple measures, as showed, to prevent Covid-19 infection within prisons, which have so far been quite effective. Nevertheless, the risk posed by the pandemic in the social environment and in prisons remains active. Therefore, prisons must still maintain the most effective prevention measures applied, like the ones discussed in this paper.

\section{Disclosure statement}

No potential conflict of interest was reported by the author(s).

\section{References}

Aebi, M. F., Berger-Kolopp, L., Burkhardt, C., \& Tiago, M. M. (2019). Prisons in Europe 2005-2015 Volume 2: Sourcebook of prison statistics. Council of Europe.

Aebi, M. F., \& Tiago, M. M. (2018). SPACE I - 2018 - Council of Europe Annual Penal Statistics: Prison populations. Council of Europe.

Aebi, M. F., \& Tiago, M. M. (2020). Prisons and prisoners in Europe in pandemic times: An evaluation of the short-term impact of the COVID-19 on prison populations. Council of Europe. http://wp.unil. ch/space/files/2020/06/Prisons-and-the-COVID-19_200617_FINAL.pdf

Aebi, M. F., Tiago, M. M., \& Burkhardt, C. (2016). Council of Europe Annual Penal Statistics SPACE I: Prison populations. Survey 2015. Council of Europe.

Afonso, P. (2020). The impact of the COVID-19 pandemic on mental health. Acta Medica Portuguesa, 33(5), 351-358. https://doi.org/10.20344/amp.13877

Ashby, M. P. J. (2020). Initial evidence on the relationship between the coronavirus pandemic and crime in the United States. Crime Science, 9, 6. https://doi.org/10.1186/s40163-020-00117-6

Assessoria Técnica à Tomada de Decisão Judicial Execução de Penas e Medidas na Comunidade Áreas Penal e Tutelar Educativa [Judicial Court Decisions for Adults and Juveniles on Penal and Community Sentences Statistics]. (2020, August). CCCRE/DGRSP.

Atkin-Plunk, C. A. (2020). Should all violent offenders be treated equally? Perceptions of punishment and rehabilitation for violent offenders with varying attributes. Victims \& Offenders, 15(2), 218-242. https://doi.org/10.1080/15564886.2019.1711277

Bedford, J., Enria, D., Giesecke, J., Heymann, D. L., Ihekweazu, C., Kobinger, G., Ungchusak, K., Oh, M.-D., Sall, A. A., Schuchat, A., Ungchusak, K., Wieler, L. H., \& Lane, H. C. (2020). COVID19: Towards controlling of a pandemic. The Lancet, 395(10229), 1015-1018. https://doi.org/10. 1016/S0140-6736(20)30673-5 
Bobbio, A., Arbach, K., \& Vazsonyi, A. T. (2018). Self-control and deviance: A test of the general theory of crime in Argentina. Victims \& Offenders, 14(1), 119-142. https://doi.org/10.1080/ 15564886.2018.1552222

Byrne, J., Kras, K. R., \& Marmolejo, L. M. (2019). International perspectives on the privatización of corrections. Criminology \& Public Policy, 18(2), 477-503. https://doi.org/10.1111/1745-9133.12440

Byrne, J. M., Pattavina, A., \& Taxman, F. F. (2015). International trends in prison upsizing and downsizing: In search of evidence of a global rehabilitation revolution. Victims \& Offenders, 10(4), 420-451. https://doi.org/10.1080/15564886.2015.1078186

Campbell, K. M., \& Doshi, R. (2020). The coronavirus could reshape global order. Foreign Affairs, 18.

Centre d'Iniciatives per la Reinserció. (2020). Informe sobre l'afectació de la COVID-19 a l'activitat laboral als centres penitenciaris [Report on COVID-19 at work in prisons]. Unpublished internal report. Departament de Justícia.

Cid, J. (2008). El incremento de la población reclusa en España entre 1996-2006: Diagnóstico y remedios [The increase of prison population in Spain between 1996-2006]. Revista Española de Investigación Criminológica (REIC) Art. 2, Núm 6, 1-30.

Cid, J. (2020). El futuro de la prisión en España [The future of imprisonment in Spain]. Revista Española de Investigación Criminológica (REIC), Art. 1, Núm., 18, 1-32.

Contini, C., Di Nuzzo, M., Barp, N., Bonazza, A., De Giorgio, R., Tognon, M., \& Rubino, S. (2020). The novel zoonotic COVID-19 pandemic: An expected global health concern. The Journal of Infection in Developing Countries, 14(3), 254-264. https://doi.org/10.3855/jidc.12671

Coyle, A., Fair, H., Jacobson, J., \& Walmsley, R. (2016). Imprisonment worldwide: The current situation and an alternative future. Policy Press.

CPCWG. (2020a, April). COVID-19 related statement by the members of the Council for Penology Cooperation Working Group. PC-CP (2020) 5. Council of Europe.

CPCWG. (2020b). Statement of principles relating to the treatment of persons deprived of their liberty in the context of the coronavirus disease (COVID-19) pandemic. CE print. CPT/Inf(2020)13. Council of Europe.

Cullen, F. T. (2007). Make rehabilitation corrections' guiding paradigm. Criminology \& Public Policy, 6(4), 717-728. https://doi.org/10.1111/j.1745-9133.2007.00469.x

DGEPRS. (2020a). Actuaciones de contención del virus en los establecimientos penitenciarios [Actions to contain the virus in prison facilities]. Unpublished internal report. Dirección General de Ejecución Penal y Reinserción Social, Secretaría General de Instituciones Penitenciarias Ministerio del Interior.

DGEPRS. (2020b). Nuevas actuaciones en los centros penitenciarios para la gestion de la situación de crisis sanitaria ocasionada por el Covid-19. Unpublished internal report. Secretaría General de Instituciones Penitenciarias, Ministerio del Interior.

DGEPRS. (2020c). Informe sobre la evolución de los internos clasificados en regimen abierto $y$ regimen de vida extra-penitenciario [Report on the evolution of prisoners classified in open and extra-prison life regimes]. Unpublished internal report. Dirección General de Ejecución Penal y Reinserción Social, Secretaría General de Instituciones Penitenciarias Ministerio del Interior.

DGEPRS. (2020d). Informe sobre los movimientos de altas y bajas que efectan a la ocupación de los centros penitenciarios [Report on the movements of discharges and discharges that affect the occupation of penitentiary centers]. Unpublished internal report. Dirección General de Ejecución Penal y Reinserción Social, Secretaría General de Instituciones Penitenciarias Ministerio del Interior.

DGEPRS. (2020e). Informe sobre los penados clasificados en cada grado de tratamiento penitenciario [Report on the convicts classified in each grade of prison treatment]. Unpublished internal report. Dirección General de Ejecución Penal y Reinserción Social, Secretaría General de Instituciones Penitenciarias Ministerio del Interior.

DGEPRS. (2020f). Medidas Nueva Normalidad (COVID-19 [New normal measures (COVID-19)]. Dirección General de Ejecución Penal y Reinserción Social, Secretaría General de Instituciones Penitenciarias Ministerio del Interior. 
DGEPRS. (2020g). Aclaración Nueva Normalidad (COVID-19) [Clarifications New Normal (COVID19)]. Unpublished internal report. Dirección General de Ejecución Penal y Reinserción Social, Secretaría General de Instituciones Penitenciarias Ministerio del Interior.

DGEPRS. (2020h). Medidas actuación (COVID-19). [Action measures (COVID-19)]. Unpublished internal report. Dirección General de Ejecución Penal y Reinserción Social, Secretaría General de Instituciones Penitenciarias Ministerio del Interior.

DGEPRS (2020i). Actividades educativas 20/21 [Educational activities 20/21]. Unpublished internal report. Dirección General de Ejecución Penal y Reinserción Social, Secretaría General de Instituciones Penitenciarias Ministerio del Interior.

DGEPRS. (2020j). Informe sobre penados clasificados 27/ 08/2020 [Report on the convicts classified 27/08/2020]. Unpublished internal report. Dirección General de Ejecución Penal y Reinserción Social, Secretaría General de Instituciones Penitenciarias Ministerio del Interior.

Di Lorenzo, G., \& Di Trolio, R. (2020). Coronavirus disease (COVID-19) in Italy: Analysis of risk factors and proposed remedial measures. Frontiers in Medicine, 7, 140. https://doi.org/10.3389/ fmed.2020.00140

Directorate-General of Health. (2020). Situation report of Portugal. Ministry of Health. https:// covid19.min-saude.pt/ponto-de-situacao-atual-em-portugal/

Duarte, R., Furtado, I., Sousa, L., \& Carvalho, C. (2020). The 2019 novel coronavirus (2019-nCoV): Novel virus, old challenges. Acta Medica Portuguesa, 33(3), 155-157. https://doi.org/10.20344/ amp. 13547

Duwe, G., \& Clark, V. (2017). The rehabilitative ideal versus the criminogenic reality: The consequences of warehousing prisoners. Corrections, 2(1), 41-69. https://doi.org/10.1080/23774657. 2016.1240596

Estatística Mensal Centros Educativos [Educational Centers Statistical Indicators]. (2020, August). CCCRE/DGRSP.

Estatística Mensal das Penas e Medidas com Vigilância Eletrónica [Electronic surveillance Statistics]. (2020, August). CCCRE/DGRSP.

European Prison Observatory. (2020). COVID-19: What is happening in European Prisons? (Update \#3). European Prison Observatory. http://www.prisonobservatory.org/upload/ 17042020European_prisons_during_covid19\%233.pdf

European Union Agency for Fundamental Rights. (2020). Coronavirus COVID-19 outbreak in the EU Fundamental Rights Implications. European Union Agency for Fundamental Rights. https://fra. europa.eu/sites/default/files/fra_uploads/portugal-report-covid-19-april-2020_en.pdf

EuroPris. (2020a, March 30). Overview of European prison services' responses to the COVID-19 crisis. EuroPris. https://www.europris.org/covid-19-prevention-measures-in-european-prisons/

EuroPris. (2020b, July 24). Overview of European prison services' responses to the COVID-19 crisis (3rd ed.). EuroPris. https://www.europris.org/covid-19-prevention-measures-in-european-prisons/

Farrington, D. P., Loeber, R., \& Ttofi, M. M. (2012). Risk and protective factors for offending. In B. Welsh \& D. P. Farrington (Eds.), The Oxford handbook of crime prevention (pp. 46-69). Oxford University Press.

Fazel, S., \& Baillargeon, J. (2011). The health of prisoners. The Lancet, 377(9769), 956-965. https:// doi.org/10.1016/s0140-6736(10)61053-7

Felson, M. (2006). Crime and nature. Sage.

Felson, M. (2008). Routine activity approach. In R. Wortley \& L. Mazerolle (Eds.), Environmental criminology and crime analysis (pp. 1-18). Willam Publishing.

Felson, M. (2014). Lectio: El estudio científico del delito [Lectio: The Scientific Study of Crime]. Ceremonial of the academic act of investiture as Doctor Honoris Causa of Professor Marcus Felson at the Miguel Hernández University. Universidad Miguel Hernández.

Fiscal de Sala Delegado de Vigilancia Penitenciaria. (2020, Abril). Nota de Servicio 2/2020: Efectos de la paralización de los programas de trabajos en beneficio de la comunidad por razones de emergencia sanitaria [Service Note 2/2020: Effects of the stoppage of community service programs for reasons of health emergency]. Fiscalía General del Estado.

Flanigan, T. P, Zaller, N., Taylor, L., Beckwith, C., Kuester, L., Rich, J., \& Carpenter, C. C. J. (2009). HIV and infectious disease care in jails and prisons: Breaking down the walls with the help of 
academic medicine. Transactions of the American Clinical and Climatological Association, 120, 73-83.

Gonçalves, L., \& Gonçalves, R. A. (2012). Agressividade, estilo de vida criminal e adaptação à prisão [Aggressiveness, criminal lifestyle and adaptation to prison]. Psicologia USP, 23(3), 559-584. https://doi.org/10.1590/S0103-65642012005000013

Gonçalves, R. A. (2007). Promover a mudança em personalidades anti-sociais e psicopatas: Punir, tratar e controlar [Promoting change in antisocial personalities and psychopaths: Punishing, treating and controlling]. Análise Psicológica, 25(4), 571-583. https://doi.org/10. 14417/ap.466

Gonçalves, R. A., Valente, D., Andrade, J., \& Castro-Rodrigues, A. (2019). How inmates and prison officers perceive prison: An exploratory study. In G. Mowll (Ed.), A closer look at prisons and prison inmates (pp. 1-36). Nova Science Publishers.

Hoff, G., Fedosejeva, R., \& Mihailescy, L. (2009). Prison preparedness for pandemic flu and the ethical issues. Public Health, 123(6), 422-425. https://doi.org/10.1016/j.puhe.2009.04.003

$\mathrm{Hu}$, L., Zhang, W., Jin, R., Liang, L., Xu, B., \& Hu, Z. (2020). Risk factors associated with clinical outcomes in 323 COVID-19 hospitalized patients in Wuhan, China. Clinical Infectious Diseases, 52 (7), 498-505. https://doi.org/10.1093/cid/ciaa539

IACHR. (2020). IACHR calls on states to protect and preserve the work of human rights defenders during the COVID-19 pandemic. Inter-American Commission on Human Rights. https://www.oas. org/en/iachr/

Liebrenz, M., Bhugra, D., Buadze, A., \& Schleifer, R. (2020). Caring for persons in detention suffering with mental illness during the COVID-19 outbreak. Forensic Science International: Mind and Law, 1, Article 100013. https://doi.org/10.1016/j.fsiml.2020.100013

Lum, C., Maupin, C., \& Stoltz, M. (2020). The impact of COVID-19 on law enforcement agencies (wave 1). International Association of Chiefs of police. https://www.theiacp.org/sites/default/files/IACPGMUsurvey.Pdf

Ma, C., Rogers, J. H., \& Zhou, S. (2020). Global economic and financial effects of 21st century pandemics and epidemics. SSRN.

Martín, A. M., Padrón, F., \& Redondo, S. (2019). Early narratives of desistance from crime in different prison regimes. The European Journal of Psychology Applied to Legal Context, 11(2), 71-79. https:// doi.org/10.5093/ejpalc2019a2

Maruschak, L., Sabol, W., Potter, R., Reid, L., \& Cramer, E. (2009). Pandemic influenza and jail facilities and populations. American Journal of Public Health, 99(2), S339-S344. https://doi.org/10. 2105\%2FAJPH.2009.175174

MI. (2020a). Balance de criminalidad de 2019 [Crime in Spain in 2019].

MI. (2020b). Balance de criminalidad. Primer trimestre del año 2020 [Crime balance. First quarter of the year 2020].

Millan, P. (2020, June 18). Coronavirus España: Cifras, contagiados y última hora de la nueva normalidad, en directo [Coronavirus Spain: Figures, infected and last minute of the new normal, live]. La Vanguardia (Newspaper).

Miró, F. (2011). La oportunidad criminal en el ciberespacio. Aplicación y desarrollo de la teoría de las actividades cotidianas para la prevención del cibercrimen [The criminal opportunity in cyberspace. Application and development of the routine activities theory for the prevention of cybercrime]. Revista Electrónica de Ciencia Penal y Criminología, 13-07, 1-55. http://criminet.ugr.es/recpc

Moreira, J., \& Martins, M. (2019). Estatísticas [Statistics]. Sombras e Luzes, 2, 181-230. https://dgrsp. justica.gov.pt/Revista-Sombras-e-Luzes

Moss, S. A., Lee, E., Berman, A., \& Rung, D. (2018). When do people value rehabilitation and restorative justice over the punishment of offenders? Victims \& Offenders, 14(1), 32-51. https://doi. org/10.1080/15564886.2018.1539688

Mossos d'Esquadra. (2020). Informe sobre la delinqüència en Catalunya [Report on Crime in Catalonia]. Departament d'Interior.

Ngo, F. T., \& Paternoster, R. (2011). Cybercrime victimization: An examination of individual and situational level factors. International Journal of Cyber Criminology, 5(1), 773-793. 
Penal Reform International. (2020). Coronavirus: Healthcare and human rights of people in prison. Briefing note. Penal Reform International. https://www.penalreform.org/resource/coronavirushealthcare-and-human-rights-of-people-in/

Policía Nacional. (2020). Informe sobre la delincuencia en España [Report on crime in Spain]. Ministerio del Interior.

Portuguese Council of Ministers of March 12. (2020). Medidas extraordinárias de resposta à epidemia do novo coronavirus [Extraordinary measures to respond to the new coronavirus epidemic]. Goverment of Portugal. https://www.portugal.gov.pt/pt/gc22/governo/comunicado-de-conselhode-ministros? $\mathrm{i}=330$

Redondo, S. (2008). Individuos, sociedades y oportunidades en la explicación y prevención del delito: Modelo del Triple Riesgo Delictivo (TRD) [Individuals, societies and opportunities in the explanation and prevention of crime: Model of Triple Risk Factors for Crime (TRD)]. Revista Española de Investigación Criminológica, Artículo 7, N. 6. www.criminologia.net

Redondo, S. (2015). El origen de los delitos: Introducción al estudio y explicación de la criminalidad [The origin of crimes: Introduction to the study and explanation of crime]. Ed. Tirant lo Blanch.

Redondo, S. (2017). Evaluación y tratamiento de delincuentes [Assesment and treatment of offenders]. Ed. Pirámide.

Redondo, S., \& Frerich, N. (2014). Crime and justice reinvestment in Europe: Possibilities and challenges. Victims \& Offenders, 9(1), 13-49. https://doi.org/10.1080/15564886.2013.864525

Redondo, S., \& Garrido, V. (2013). Principios de Criminología (4a ed.) [Principles of criminology]. Tirant lo Blanch.

Reyns, B. W., Henson, B., \& Fisher, B. S. (2014). Digital deviance: Low self-control and opportunity as explanations of sexting among college students. Sociological Spectrum: Mid-South Sociological Association, 34(3), 273-292. https://doi.org/10.1080/02732173.2014.895642

Sanchez, A., Simas, L., Diuana, V., \& Larouze, B. (2020). COVID-19 in prisons: An impossible challenge for public health. Cadernos de Saúde Pública, 36(5), 1-5. https://doi.org/10.1590/0102$311 \times 00083520$

Sánchez, F. (2020, July 10). Portugal entra en la lista negra por el azote del virus [Portugal enters the blacklist due to the scourge of the virus]. El País (Newspaper).

Sappal, P. (2020, April 23). Portugal starts mass testing for Covid-19 to help lift lockdown restrictions quicker \& attract tourists back. Euroweekly.

SMPRAV. (2020a). Pla d'acció per a la transició del confinament pel COVID-19 als centres penitenciaris [Action plan for the transition from COVID-19 confinement at the prison context]. Unpublished internal report. Secretaria de Mesures Penals, Reinserció i Atenció a la Víctima, Departament de Justícia.

SMPRAV. (2020b). Protocol d'actuació als centres penitenciaris de Catalunya per a la gestió de la situació de crisi sanitària ocasionada pel COVID-19 [Protocol of action in the prison centers of Catalonia for the management of the situation of sanitary crisis caused by the COVID-19]. Unpublished internal report. Secretaria de Mesures Penals, Reinserció i Atenció a la Víctima, Departament de Justícia.

SMPRAV. (2020c). Adaptació de la fase de represa als centres peniteciaris [Adaptation of the resumption phase to prisons]. Unpublished internal report. Secretaria de Mesures Penals, Reinserció i Atenció a la Víctima, Departament de Justícia.

SMPRAV. (2020d). Adaptació de la fase de represa als centres peniteciaris. Mesures provisionals per la represa progressiva de les comunicacions especials a partir del 21 de setembre [Adaptation of the resumption phase to prisons. Provisional measures for the gradual resumption of special communications from 21 September]. Unpublished internal report. Secretaria de Mesures Penals, Reinserció i Atenció a la Víctima, Departament de Justícia.

Solar, P., \& Lacal, P. (2020). Europa ante el Covid-19. Referencias específicas al Derecho penitenciario. Revista Aranzadi Unión Europea, N. 7.

Stickle, B., \& Felson, M. (2020). Crime rates in a pandemic: The largest criminological experiment in history. American Journal of Criminal Justice, 45(4), 525-536. https://doi.org/10.1007/s12103-02009546-0 
Stoliker, B. E., \& Galli, P. M. (2019). An examination of mental health and psychiatric care among older prisoners in the United States. Victims \& Offenders, 14(4), 480-509. https://doi.org/10.1080/ 15564886.2019 .1608883

UNODC. (2020). COVID-19 preparedness and responses in prison. UNODC. https://www.unodc.org/ documents/justice-and-prison-reform/UNODC_Position_paper_COVID-19_in_prisons.pdf

Wade, L. (2020, May). From Black Death to fatal flu, past pandemics show why people on the margins suffer most. Science, 368(6492), 700-703. https://doi.org/10.1126/science.abc7832

Ward, T., \& Fortune, C. A. (2016). The role of dynamic risk factors in the explanation of offending. Aggression and Violent Behavior, 29(July-August), 79-88. https://doi.org/10.1016/j.avb.2016.06. 007

WHO. (2020a). Preparedness, prevention and control of COVID-19 in prisons and other places in detention. (Interim guidance). WHO. http://www.euro.who.int/_data/assets/pdf_file/0019/ 434026/Preparedness-prevention-and-control-of-COVID-19-in-prisons.pdf?ua=1

WHO. (2020b). WHO announces COVID-19 outbreak a pandemic. WHO. https://www.euro.who.int/ en/health-topics/health-emergencies/coronavirus-covid-19/news/news/2020/3/who-announcescovid-19-outbreak-a-pandemic

WHO. (2020c). 2019 novel coronavirus (2019-nCoV): Strategy preparedeness and response plane. https://www.who.int/publications/i/item/strategic-preparedness-and-response-plan-for-the-newcoronavirus

WHO Director-General's Special Envoys on COVID-19 Preparedness and Response. (2020). WHO. https://www.who.int/emergencies/diseases/novel-coronavirus-2019/who-director-general-s-spe cial-envoys-on-covid-19-preparedness-and-response

World Prison Brief. (2020). World prison brief data: Portugal. World Prison Brief. https://www. prisonstudies.org/country/portugal

Zafra, M., Blanco, P., \& Sevillano, L. (2020July17). Casos confirmados de coronavirus en España y en el mundo [Confirmed cases of coronavirus in Spain and in the world]. El País (Newspaper). 